\title{
La resta de Alia Trabucco
}

\section{Ana Eva Rodríguez Valentín*}

Alia Trabucco en su novela La resta nos guía en un recorrido por el tiempo y el espacio chilenos, a través de dos miradas que, en apariencia, se contraponen, pero que a su vez se complementan para hacer partícipe al lector de una realidad, que solo puede ser entendida desde la confrontación de las distintas versiones de un mismo acontecimiento: el régimen opresivo de Pinochet y las posteriores secuelas que, tras el fin de la Dictadura en 1990, perdurarían no solo en las generaciones implicadas, sino también en las posteriores.

El regreso de Paloma a Santiago de Chile, así como la noticia de la muerte de su madre, Ingrid Aguirre, exiliada de la Dictadura y miembro de la Resistencia chilena, supondrá una brecha en la vida de Consuelo (antigua compañera de militancia) y su hija Iquela.

Paloma, desde Alemania, dispone todo para que el cuerpo de su madre sea repatriado, pero, al aterrizar, le informan de que el ataúd con el cadáver se dirige hacia Mendoza, ya que no habían compartido el mismo vuelo. A partir de este momento, comenzará para ella e Iquela una difícil tarea: encontrar el cuerpo de Ingrid y poder retornarlo a su lugar de origen, Santiago de Chile.

Este trastorno también llegará a la vida de Felipe, amigo de Iquela, y que se presenta como la otra cara de la moneda que hace girar todo el argumento. Volver a mirar hacia el pasado nos trae la certeza de su propia construcción íntima, a través de la memoria y la necesidad de amoldar los hechos para arreglar - aunque unicamente sea a través de su alteración-lo que no pudimos cambiar en el pasado. El hecho traumático significó una ruptura respecto a la percepción de los acontecimientos posteriores. Consuelo, testigo de primera fila del régimen militar, recibe a la hija de Ingrid "Como si una cara detrás de su propia cara se alegrara, o su expresión de joven, de Consuelo, no de mi madre, asomara pronto para darle la bienvenida a Ingrid, no a Paloma."(60). El desfase con esta

\footnotetext{
*Universidad de Salamanca, España. aerodriguez@usal.es
} 
realidad otra, que se presenta como un nuevo acontecer en un tiempo pasado, impide adaptarse a un orden distinto de los hechos.

Bajo el concepto de posmemoria, aunque su origen esté ligado a los relatos de los hijos de supervivientes del Holocausto, podemos entender los nuevos relatos latinoamericanos como sostiene Hirsch. A partir de la Posmodernidad se pondrá el acento en las miradas marginales o menores que intentan, de modo alguno, romper con la Historia Oficial establecida. Dicha perspectiva ya está presente en la narrativa chilena actual como pueda ser Formas de volver a casa de Alejandro Zambra; así como la obra fílmica Machuca, de Andrés Wood, que pone el énfasis en la mirada de un niño. Esto permite observar los hechos a través de un prisma distinto, esto es, fuera del vivo acontecimiento para llegar a una visión más amplia; y por consiguiente, a un juicio más crítico. En La resta, el relato se entreteje a través de un diálogo constante entre la memoria de los padres que se adhiere — casi inevitablemente— a la generación de los hijos; quienes fueron forjando su sentir y sus estructurales mentales en torno a un pasado fuerte del que jamás serían protagonistas, sino meros marginados de la historia: "Jamás conversábamos cara a cara [...] Mis ojos eran el problema; no sabían sostener esa mirada (sostener el peso de todas las cosas que ella había visto"(47).

Lo interesante en la escritura de Trabucco es que sus jóvenes personajes no desean entrar en ese protagonismo, desean romper con el pasado; dejar de vivir a través del nombre de otros: “[...] tú tienes los ojos de tu papá, me decía mi abuela Elsa, los tienes igualitos, y yo me esfuerzo y digo no, eso es mentira, [...] no tengo los ojos de ningún papá, mis ojos son míos, míos, míos, yo soy hijo de los pétalos y de mi chozna y de mí mismo, eso soy, hijo de mí mismo [...]" (257).

La angustia con que, desde el principio de la novela, Felipe da cuenta de la hazaña que intenta lograr — ser capaz de contar cuántas personas "realmente" mueren- nos persigue a lo largo de todo el relato; todo ello, para hacernos entender que la vida no se puede apresar bajo simples datos, sino que el entramado de la vida se construye únicamente a través de las partes - aquellas que no caben en una sola cifra entera-. Y solo por medio del contacto directo con estas experiencias, mediante el artificio literario en este caso, llega la comprensión. Es esencial, en este sentido, el pasaje en que este mismo personaje habla de un pájaro que tuvo en la infancia. Una frase que su abuela Elsa siempre le repetía, sobre 
la belleza interior, le empuja a asesinar a su loro Evaristo. Esta primera experiencia con la muerte condiciona toda su existencia. A este hecho se suma su muerte administrativa, puesto que el padre de Iquela, Rodolfo, cuando es detenido por la policía da su nombre: Felipe Arrabal. Ahora, bajo ese nombre solo consta presunción de muerte. Los contextos, por tanto, son los grandes configuradores de los individuos.

Así pues, se hace hincapié en esa necesidad de hacer cuentas, de reajustar una realidad que no coincide con la que se narra. Se trata de encontrar un lugar para "los muertos-vivos" como el propio Felipe. Y también de luchar contra un discurso que a través de la aritmética neutraliza la vida y nos hace contar huesos, las partes del cuerpo como piezas ajenas a lo que un día fue la vida del ser humano. Por eso "[...] cuando hay muertos se debe aullar, sí, aullar hasta que no haya voz, hasta que no haya nada" (56). La ironía con que se plantea el final de la novela dice mucho de lo irresoluto de ese "ajuste de cuentas". Cuando finalmente logran recuperar el ataúd que contiene el cuerpo de Ingrid Aguirre, Felipe huye despavorido con él: este es el intento personal de saldar unas cuentas, que deberían ser de todos: “[...] En realidad, ¿qué importa de quién sean los muertos, no? El problema no es ese, dijo más convencido. Hay que ayudarse con los muertos; hay demasiados." (264).

El paso de un estadio a otro, de la muerte a la vida, es demasiado frágil. El proceso de muerte — definida en ocasiones como una instancia del sistema - acecha a la población chilena, también, a través de otro fenómeno que sobreviene y condiciona la construcción del sujeto: los seísmos. En La resta, este hecho, no predecible, parece haber creado una cartografía propia: “[...] los temblores, los terremotos, nadie sabe cuándo puede venir el descalabro, Iquela, quítalos todos, por favor, me había dicho, y las paredes se habían poblado de cicatrices que yo reconocía como un perfecto mapa de la casa" (59). A pesar de que este espacio concreto se define como un espacio herido "lleno de cicatrices" es, para Consuelo, el único espacio donde se siente a salvo.

La ciudad aparece como búsqueda y huida, como necesidad y rechazo; en definitiva, la urbe mantiene una tensión de pertenencia con los protagonistas de las distintas generaciones. Los personajes mencionan la posibilidad de marcharse, pero nunca se deciden a ello. Y cuando parten hacia Mendoza - por la obligación moral para con el cadáver de Ingrid que, antes de morir, pidió la repatriación- la limpidez 
del cielo argentino les parece atroz. Un deseo de volver a ver el ceniciento paisaje chileno, causado por la explosión de un volcán, rodea a Iquela. Esta imagen se convierte en metáfora de la vida santiaguina que propone Trabucco: “Una mortaja gris sobre Santiago” (145).

Así, ciudad y muerte se entrecruzan dando como resultado una peculiar visión de Santiago de Chile; imagen que conecta con los acontecimientos de la historia chilena que forjó a su antojo dichos espacios, y podríamos añadir, a sus habitantes: “[...] porque me encubro hasta no ver más que el cauce del Mapocho, esa curva que conozco como a mí mismo, porque la cuenca del río está enterrado en mi piel, en la línea de la palma de mi mano, el cauce de mi sangre atraviesa la ciudad, esta ciudad que es mi cuerpo [...]" (278). 